Александра Б. Вранеш

\title{
СРПСКО ЈЕЗИЧКО И КЊИЖЕВНО БИВСТВО У БИБЛИОГРАФИЈИ
}

Српска библиографија, условљена постојањем државних и конфесионалних језика у прошлости, релативно касном појавом високошколских и научних институција, сеобама српског народа, нестабилношћу државних граница, разуђеношћу порекла аутора, треба да обезбеди јединство српске књиге. Кроз историју, етнички принцип је био присутан у одређивању дома библиографије, данас је примаран лингвистички, на шта утиче, вероватно, више фактора: доминација класификационих система у којима је језичко одређење примарно; Интернет са превагом енглеског као језика претраживања, али и изворног облика објављивања електронских извора; распрострањеност употребе једног језика на ширем подручју независно од етничке припадности групе и појединца; преферирање доминантног језика комуникације како би се постигло уклањање језичких баријера и повећање доступности литературе на ширем подручју.

Друга половина XX, још више почетак XXI века, мада су у животу одржавале поделе стваралаца управо према националном критеријуму, у библиографији су, дакле, подстакле превагу језичких доминанти, што је проузроковало изједначавање књижевне националности са грађанском. Српска ретроспективна библиографија поштује комбиновани национално-језичко-историјско-географски принцип, док је у бележењу текуће издавачке продукције, која покрива и периодику и аналитику, чак цензурисала сопствено национално биће и маћехински се односила према 
свим ауторима који му људски и културолошки припадају, а живе и стварају ван граница данашње Србије. Ако само не бисмо сами одступали од потребе за очувањем националне баштине и културног бивства, ако бисмо у глобалном могли да очувамо локално, а не да га сами цензуришемо, могли бисмо да се дичимо српским језиком, српском књижевношћу и српском библиографијом.

Кључне речи: српски језик, српска књижевност, српска библиографија.

Српска библиографија, условљена постојањем државних и конфесионалних језика у прошлости, релативно касном појавом високошколских и научних институција, сеобама српског народа, нестабилношћу државних граница, разуђеношћу порекла аутора, треба да обезбеди јединство српске књиге. Кроз историју, етнички принцип је био присутан у одређивању припадности аутора националној библиографији, данас је примаран лингвистички, на шта утиче, вероватно, више фактора: доминација класификационих система у којима је језичко одређење примарно; Интернет са превагом енглеског као језика претраживања, али и изворног облика објављивања електронских извора; распрострањеност употребе једног језика на ширем подручју независно од етничке припадности групе и појединца; преферирање доминантног језика комуникације како би се постигло уклањање језичких баријера и повећање доступности литературе на ширем подручју.

Друга половина XX, још више почетак XXI века, мада су у животу одржавале поделе стваралаца управо према националном критеријуму, у библиографији су, дакле, подстакле превагу језичких доминанти, што је проузроковало изједначавање књижевне национално- 
сти са грађанском. Српска ретроспективна библиографија поштује комбиновани национално-језичко-историјско-географски принцип, док је у бележењу текуће издавачке продукције, која покрива и периодику и аналитику, чак цензурисала сопствено национално биће и маћехински се односила према свим ауторима који му људски и културолошки припадају, а живе и стварају ван граница данашње Србије.

Може ли се на пољу библиографије допустити кодификовање, формализовање иновације, фетишизација идеје уместо решавања трајних хуманистичких задатака, уз уважавање културног наследства? Или библиографији треба обезбедити комуникативност са домаћом и страном јавношћу, којој је предуслов њена добро утемељена, разуђена, квалитетна дистрибуција? Интеграција свих видова библиографије, нарочито националне, и текуће и ретроспективне, у целовити научни систем једне земље и њену свакодневицу, обезбеђује потврђивање националног идентитета, мост је, како каже Људмила Викторовна Астахова, «који сједињује кванте знања с објективним светом» (Астахова 1997: 23-32).

Националну библиографију подржава, подстиче, развија, оплемењује, оживотворује завичајна библиографија. Културне иновације проистичу из културног архетипа. И српска библиографија данас треба да укључи критеријуме који су у нас поступно стасавали од 1766. године, од загубљеног Каленgара и потом, 1768. године, Славено-сербскої маїазина Захарија Орфелина, чија су Известиија о учених gјелах исходиште библиографске мисли у Србији и реформаторског опредељења да се нова издања најаве и представе публици. Орфелиновом установљењу текуће и перспективне библиографије континуитет су обезбеђивали браћа Маркидес-Пуљо, Стефан Новаковић, Димитрије Давидовић и Димитрије Фрушић, потом Георгије Магарашевић, Милош Светић, Теодор 
Павловић, Милош Поповић, Јован Суботић, неколико последњих као приложници Лейойиса срӣской, гласила Матице српске. Од смесица, често несистематизованих, непроверених, непотпуних, које су ублажавале недовољност информисања српског живља о књижевним и културним дешавањима и подстицале на објављивање библиографија, у кратком временском распону стигло се до ауторских библиографија, чији се профил препознавао. У првој половини 19. века Димитрије Тирол је текућу библиографију обликовао по територијалном принципу, наглашавајући у њој критеријум завичајности, усмеравајући тако делатност већине библиографа, укључујући и Стојана Новаковића. Док је ретроспективна библиографија ненаметљиво и потпуно самостално примењивала и територијални, и национални, и лингвистички критеријум, према којима се и данас обликује, текућа библиографија се безразложно ограничавала на територијални. Промену је унео Ђура Даничић, чија текућа библиографија 1858. године садржи српске књиге и нове књиге на другим језицима које се тичу Срба и то «само оне које су у Београд добављене». Од прописно устројене Даничићеве развила се Новаковићева, а потом и Бошковићева, текућа библиографија у Гласнику Срйскоі ученої gрушӣва, обухватајући српску и хрватску књижевност, с белешкама онога што је на страним језицима о нама писано. Лингвистички критеријум у српску библиографију уноси критика библиографије, а не сама библиографија, односно Луј Леже који Стојану Новаковићу предочава пропуст узрокован ћирилицом, а не и латиницом, као писмима српске књижевности. У годинама 1917. и 1918, растужени што су остали «без библиотека, без литературе, без најосновнијих библиографских бележака и то у тренуцима кад нам је свежа и здрава душевна храна најпотребнија» Срби су с нарочитом пажњом пратили публикације штампане у изгнан- 
ству. Бележење нових наслова неговано је у међуратном периоду на страницама Политиике, Правgе, Времена, Шйамйе, док су часописи научне оријентације, попут Јужнословенскої филолоїа, Прилоїа за кюижевности, језик, исӣорију и фолклор, текућој библиографији све чешће обезбеђивали редовну рубрику. Текућа библиографија је наново, као и више пута раније, проистекла из рада на ретроспективној библиографији. Павле Поповић, који је са групом студената и сарадника организовао рад на настављању Новаковићеве ретроспективне библиографије за године 1868. до 1905, допринео је институционализовању библиографских истраживања и оснивању Библиографског института на Филозофском факултету 1920. године, што је почетак организованог бележења српске текуће библиографије, али за кратко. Библиоіраф, йойс нових књйіа и иериоgичних ӣубликација Кралевине СХС, који је излазио у Београду сваког месеца од 1926. године, Јуїословенски библиоірафски іодишььк за 1933. Народне библиотеке Србије, месечне свеске Јуїословенске библиоірабије Гласника књижара и Гласника Нароgне $\delta и \delta л и о \overline{е к е ~ о б о л ~ с у ~ н о в о м ~ в р е м е н у ~ з а ј е д н и ш т в а ~ и ~ п о т и-~}$ рања националних обележја. Из тога доба остао је забележен програмски говор Душана Будимировића који текућу библиографију доживљава «као добро средство интелектуалне и практичне едукације, елемент за формирање нашег укуса, датум свога времена, историју његових идеја и мерило нашег научног и моралног темперамента» (Будимировић). Оснивањем Југословенског библиографског института 1949. почиње се са праћењем комплетне југословенске издавачке продукције. Српској библиографији враћаћемо се само спорадично и тематски сужено.

«Добра национална, нарочито текућа општа библиографија која редовно излази увек је доказ да народ који је издаје жели да живи самосталним културним животом» (Логар 1973: 129). У временима братства и јединства, на 
бившим југословенским просторима негована је текућа југословенска библиографија у оквиру Југословенског библиографског института. Осамдесетих година почињу се објављивати националне библиографије у Босни и Херцеговини (Библиоірабија босанско-хериеіовачких къиїа, Библиоірафија босанско-хериеіовачких часойиса, 1978-1983), Хрватској (Bibliografija knjiga tiskanih u SR Hrvatskoj, Bibliografija rasprava i članaka i književnih radova u časopisima SR Hrvatske 1978-1981), Македонији (Макеgонска библиоірафија : моноїрабски йубликаиии, 1982, Периодични йубликации и низи йубликачии 1984- ), Словенији (Slovenska bibliografija, 1947-1983), само не у Србији. Библиоірафија Србије и Библиоірабија Рейублике Срйске почињу да тек од 2003. представљају текућу продукцију издавача са поменутих територија. Грубо би било устврдити да нам самостални културни живот није својствен и није битан, ипак би се ваљало запитати зашто га онда не потврђујемо и не отржемо од заборава текућом националном библиографијом. Ако су аутори 18. и 19. века, у временима политички и економски нимало сређенијим и стабилнијим од данашњих, темељили текућу библиографију на територијалном, историјском, националном и лингвистичком принципу, данашња одлука српских институција културе, не може бити израз историјске условљености, већ само свесног опредељења челних људи и институција. Српска текућа библиографија одговорност је и обавеза свих нас.

Ако само не бисмо сами одступали од потребе за очувањем националне баштине и културног бивства, ако бисмо у глобалном могли да очувамо локално, а не да га сами цензуришемо, могли бисмо да се дичимо српским језиком, српском књижевношћу и српском библиографијом.

Наведимо примере везане за УДК, на којој почива стручна класификација. Овај, могли бисмо рећи, иначе племенито замишљен систем груписања људског знања, 
подразумева предметизовање помоћу вештачког нумеричког језика, захтевног, разуђеног и обимног, па стога, разумљиво, и подложног грешкама. Отвара се и питање демократичности и правичности овог класификационог система, због подређености малих у односу на велике народе. Укључено је ту и раслојавање некада јединствених књижевности према новим језичким политикама, које накнадно изводе своју историјску вертикалу. Дела свих српскохрватских писаца, на пример, који су умрли до 1993. године и данас третирамо као српскохрватску књижевност, чак и када су се декларативно изјашњавали као српски аутори, при чему многи још не схватају да српскохрватска књижевност никада и није постојала, већ књижевност на српскохрватском језику. Тешко је рекласификовати целовито културно наслеђе, али је дугорочна последица ако га добровољно препустимо онима којима не припада и грех према ауторима који су у име сопственог националног опредељења за живота осећали неправду. Само један илустративни пример, а има их хиљаде, биће цитат из писма песника и есејисте Хусеина Тахмишчића уреднику Полийике Миодрагу Максимовићу, написаног 11. децембра 1970. године: „Моја основна ситуација није нимало лака, а још мање је завидна. Изложен сам ево већ седам месеци милитантним насртајима пробуђеног муслиманског национализма. (...) То што ми се замера крајње је једноставно и злехудо. Реч је о наречју којем говорим и пишем. Реч је о мом припадању српској књижевности. (...) Ја сам какав такав писац. Ничија трансмисија, па ни етничких глупости на које моје хашемитско име упућује (Тахмишчић: 24).“ За наше каталогизаторе и библиографе Хусеин Тахмишчић је српскохрватски писац. А чији су писци аутори српског порекла који, изворно или у преводу, објављују на страним језицима. Шта одређује припаднпост писца једној књижевности: његово порекло, место рођења, или место у коме је живео или о коме је 
писао, језик и писмо на коме је стварао? Којигод да га од ових елемената одређује, његова припадност националној књижевности даје му неумољиву нумеричку ознаку и усмерава свест читлаца.

Током целог 18. и 19. века национална припадност одређивала је укљученост аутора у националну библиографију духовног стваралаштва. Друга половина 20, још више почетак 21. века, мада су у животу одржавале поделе стваралаца управо према националном критеријуму, у библиографији су подстакле превагу језичких доминанти, што је проузроковало настајање грешке, изједначавање књижевне националности са грађанском. Аутори који не припадају једном народу који говори једним језиком, уместо да буду вишеструко пласирани у различитим националним библиографијама, бивају везани само за језик на коме стварају. Дела Владимира Владимировича Набокова, од 1940. руског емигранта у САД, писана на енглеском језику, библиографски припадају америчкој, а не руској књижевности, без обзира на његово етничко порекло. Исти је случај, на пример, и са делима америчких аутора, пољског Јеврејина Исака Башевиса Зингера, либанског песника и прозаисте Џубрана Халила Џубрана. Вишенационалне књижевности, попут хиспаноамеричке, или арапске, писане су на заједничком књижевном језику. Књижевна националност разликује се често од грађанске и језичке националности. Варијанте језика (попут енглеске и америчке верзије енглеског, швајцарске варијанте немачког, португалске и бразилске варијанте португалског, хрватске, бошњачке, црногорске варијанте матичног српског језика), уколико и када у називу језика у самој класификацији нису довољно разуђене, бивају територијално, називом града, региона, или државе, одређене, али ни тада се не достиже степен прецизности какву пружа етничко одређење. Посебан књижевно-језички израз припадника бивших југосло- 
венских република у педесетогодишњем периоду био је закриљен одређењем југословенске књижевности, ради чега је садашње накнадно одређење етницитета писаца непоуздано, вишеструко условљено, можда и непотребно из личне перспективе аутора којима је југословенство било изворно опредељење. Индивидуална двојезичност писаца, истовремена, или у различитим животним раздобљима, извориште је бројних класификационих и библиографских дилема. Своје ране песме Васко Попа је писао на румунском језику; Милош Црњански Роман о Лонgону почиње да пише на енглеском, а наставља на српском језику; Силвија Монрос Стојаковић Граg наg iраgовима пише и у истој књизи објављује на српском и шпанском језику. Овакво размишљање намеће посебно питање превођења и објављивања дела са језика који није био изворни, па самим тим и погрешно национално одређење. Погрешна почетна поставка води и погрешном крајњем одговору, чему може доприносити и примена Универзалне децималне класификације.

За сваку класификациону групу постоје добра и доследна решења, као и она која су подложна критикама, самим тим и предвиђена да се мењају. Заснована на јасним научним поставкама и културним спецификумима, деценијама одржавана, примењивана, разрађивана, и даље у експанзији, Универзална децимална класификација највећа је «светска лабораторија», спутана заблудама проистеклим из научних и културних истина.

Подсетимо се још једном заблуде Стојана Новаковића да у српску ретроспективну библиографију укључи само дела штампана ћирилицом и добронамерних сугестија Луја Лежеа да нашем културном наслеђу припадају и да су српска и она дела писана латиницом, за шта је Новаковић већ у својој текућој библиографији потом имао слуха. Оживимо ово виђење тврдњом да су све књиге штампане латиницом у електронским каталозима, 
после распада Југославије, аутоматски добијале ознаку хрватске књижевности. Деценијска је била борба српског библиотекарства да се српском народу не одузме наслеђе које је настајало на латиници.

Употребу ћирилице не смеју да мотивишу разлози политичког карактера. Не сме навика да опредељује наше мишљење. Наше мишљење не сме да буде разлог међусобних удаљавања. Оно мора да буде обједињавајући фактор српског, не националног, већ животног идентитета.

У општем поступку глобализације и стварања могућности за ширење писмености, ћирилицу треба развијати у континуираном образовању, у окриљу технолошког описмењавања, као модел креативног размишљања, као наше национално писмо, којим се разрешавају многе претходне дилеме. Очување ћирилице истовремено је категорија реалности и категорија моралности опстајања српског националног идентитета. Можда смо се од ових категорија у нашој свакодневици удаљили, јер смо увезли модалитете понашања и критеријуме вредности из туђих стварности. У моралном галиматијасу лако је изгубити писмо, које је слично писмима народа из чијих нам култура данас не долазе пресирајући утицаји. Али оно је само слично, а заправо је у свету јединствено и стога га је лакше затурити, јер нам на први поглед не помаже да се уклопимо у процес глобализације. Очувати локално у глобалном није само одбрамбена домишљалица, она једнако важи и за такозване мале и велике народе, и говори у прилог ћирилице, данас каткад растрзане, а каткад занемариване чак и од нас самих који на њеном интегритету треба да устрајавамо. Истрајавајући на интегритету ћирилице, не значи да треба да се лишавамо нашег културног наслеђа које је настајало и настајаће на оба писма. Значи да не треба сами да је занемарујемо, већ да јој обезбедимо активно трајање и узлет у свим савременим медијима. Своја знања, настојања и добре намере 
треба да усмеримо у циљу очувања битка и промовисања јединствености и лепоте српске ћирилице као чиниоца националне кохезије. Српски народ треба да поштује своју традицију и историју, да чува своју културу, језик и писмо.

Закључимо ова размишљања речима српског владара и светитеља: „Запамти, чедо моје, да свако освајање и отцепљење није толико опасно за народ колико је штетно за нараштај. То може штетити само једном нараштају, а не народу. Народ је, чедо моје, трајнији од нараштаја и од сваке државе. Кад тад народ ће се спојити као вода чим пукну бране које га раздвајају. А језик, чедо моје, језик је та вода, увек иста с обе стране бране, која ће као тиха и моћна сила која брегове рони опет спојити народ у једно отачаство и једну државу.»

\section{Литература:}

Астахова, Људмила Викторовна (1997) . Библиоірафско знаюе

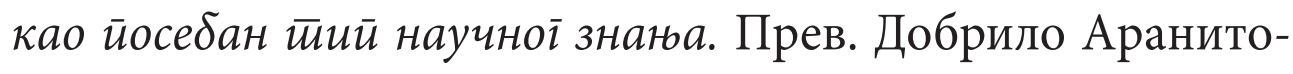
вић. Библиографија.

Будимировић: Душан Будимировић, О нароgној јуіословенској библиоіраббији - радио предавање одржано у Народној библиотеци Србије. Сачувано у Посебној библиотеци Ђорђа Живановића на Катедри за славистику Филолошког факултета Универзитета у Београду.

Вранеш 1977: Александра Вранеш, Srpska bibliografija u periodici : 1766-1941, (Библиотека Студије). Београд: „Драганић“, 1997. - 181 str.

Логар 1973: Јанез Логар, Увоg у библиоірафију. Сарајево: Свјетлост. Новаковић 1869: Стојан Новаковић, Срйска библијоірафија за новију кюижевносит: 1741-1867. - Београд, 1869.

Панковић 1982: Душан Панковић, Срӣске библиоірафије: 17661850. Београд: Народна библиотека Србије, 1982. - 415 c̄̄p. Панковић 2009: Душан Панковић, Срӣске библиоїрабије: 18511872. Нови Сад: Матица српска, 2009.

Тахмишчић: Књижевни лист. - 1 (1. јули 2002), стр. 24 


\author{
Aleksandra B. Vraneš \\ Faculty of Philology in Belgrade \\ Andrić Institute in Andrićgrad
}

\title{
SERBIAN LANGUAGE AND LITERARY BEINGNESS IN BIBLIOGRAPHY
}

\section{Summary}

The Serbian bibliography, conditioned by the existence of state and confessional languages in the past, relatively late appearance of higher education and scientific institutions, migrations of the Serbian people, instability of state borders, wide dispersion of authors' origin, should ensure the unity of the Serbian book. Throughout history, the ethnic principle was present in determining the home of the bibliography, today the linguistic principle is primary, which is probably affected by several factors: the dominance of classification systems in which the linguistic determination is primary, the Internet with the prevailing English language as the search language, but also the source form of publishing electronic sources, the widespread use of one language in a wider area, irrespective of the ethnicity of the group and the individual; preferring the dominant language of communication in order to achieve the removal of language barriers and increasing the level of availability of literature in the wider area.

The second half of the $20^{\text {th }}$ century, but even more the beginning of the $21^{\text {st }}$ century, although they kept the division of authors based on the national criterion alive, encouraged the prevailing trends of linguistic dominants in the bibliography, which caused the equalization of literary nationality with the civic one. The Serbian retrospective bibliography respects the combined national-linguistic-historical-geographical principle, while in the process of recording the current publishing production, which covers both periodicals and analytics, it even censured its own 
national being and treated as a stepmother all authors who belong to it in human and cultural terms, but who live and create beyond the boundaries of today's Serbia. If we could merely not deviate from the need to preserve our national heritage and cultural being, if we could safeguard what is local at the global level, and not censor it ourselves, we would be able to be proud of the Serbian language, Serbian literature and Serbian bibliography.

Key words: Serbian language, Serbian literature, Serbian bibliography. 